\title{
BLACK LOVE CAN KNOW NO LIMITS: CENTERING THE SUBJUGATED VOICE AND EXPERIENCE OF PRIDE AND WELL-BEING OF A BLACK QUEER WOMAN
}

Jessica Booker, BSW, Ryerson University, 2015

\author{
An MRP \\ presented to Ryerson University \\ in partial fulfillment of the \\ requirements for the degree of \\ Master of Social Work \\ in the Program of \\ Social Work
}

Toronto, Ontario, Canada 2017

๑) Jessica Booker, 2017 


\section{AUTHOR'S DECLARATION FOR ELECTRONIC SUBMISSION OF A MRP}

I hereby declare that I am the sole author of this MRP. This is a true copy of the MRP, including any required final revisions.

I authorize Ryerson University to lend this MRP to other institutions or individuals for the purpose of scholarly research.

I further authorize Ryerson University to reproduce this MRP by photocopying or by other means, in total or in part, at the request of other institutions or individuals for the purpose of scholarly research.

I understand that my MRP may be made electronically available to the public. 


\begin{abstract}
Black Love Can Know No Limits: Centering The Subjugated Voice and Experience of Pride and Well-Being of a Black Queer Woman

Master of Social Work, 2017

Jessica Booker

Program of Social Work, Ryerson University

This MRP provides unique insight into the lived reality of a black queer woman as it creates an intricate picture of what oppression entails. Auto-ethnography is used to discuss some experiences that black queer women face, as they strive for authentic self-love and wellness in a social climate of adversity. Personal transformative recollections are used to allow readers to gain an in-depth understanding as to why black queer women systemically struggle to experience authentic belonging in the queer and black communities. The powerful stories are shared in hopes of raising critical awareness and empathy within readers as they interact with black queer youth throughout society.
\end{abstract}




\section{ACKNOWLEDGEMENTS}

I would like to thank Gordon Pon for being my MRP supervisor, for having continual patience, support, and understanding of the passion I possess for this unique piece of work.

I would like to thank my colleagues and faculty in this Master's program for their genuine kindness and support throughout my MRP journey.

I would like to thank my family giving special thanks to my mother and members of my communities who have always believed in me. You have helped me through guidance and love on my journey of self-discovery and healing.

Most of all I would like to thank my service users from all walks of life, you continue to remind me of my purpose as a helper in this world. 


\section{DEDICATION}

I dedicate this work to my father Patrick Miguel Booker, his unconditional love and support through all my challenges and triumphs on my journey has led me to grow into the person I am today. His kind and generous soul lives on in the spirit world. 


\section{TABLE OF CONTENTS}

Introduction

Page \# 1

Literature Review

Page \# 4

Theoretical Framework

Page \# 23

Methodology

Page \# 33

Events \& Analysis

Page \# 37

Overall Findings

Page \# 50

Implications

Page \# 52

Conclusion

Page \# 56

References

Page \# 58 


\section{Introduction}

"Queerness is also a performative because it is not simply a being but a doing for and toward the future. Queerness is essentially about the rejection of a here and now and an insistence on the potentiality or concrete possibility for another world" (Muñoz, 2009, p. 1). This quote by Jose Esteban Muñoz sheds light onto the importance of taking actions to create transformative climates for change. Queer needs to be reimagined by folks as embracing concepts of multiple truths, uncertainty, and fluidity of the self, rather than a simplistic static identity (Eng, Halberstam, \& Muñoz, 2005; Muñoz, 2009; Shraya, 2013). This identity actively rejects notions of fixed selves, where consistent actions in advocacy must be taken to ensure that a new world arrives. In this world the voices of black queer youth are not an afterthought at the margins; rather, they begin at the center of inclusion and equity discussions. I begin this work by self-identifying as a young black queer female with the intention of embracing ambiguity and evoking curiosity. I have come to embrace the identity of queer over time. It allows me to embrace my unconventional positionality through positive reclamation of queerness. In this research I will be describing my experience as a black one; I want to emphasize that my ancestral origins are of Afro-Colombian and Chinese Hakka Jamaican descent. The way of being, knowing, and walking in the world is an inevitably complex experience. As a social work practitioner, I know that it is my responsibility to go beyond simply stating my identity as neutral where it is ever charged with lived realities and challenges that shape the person I am and will become. I will draw on the theories of black, brown, Indigenous, and racialized scholars including but not limited to; Jose Esteban Muñoz, David Eng, Moya Bailey, Cyndy Baskin, Jill 
Alears, and Katie Acosta, while focusing on queer theory, critical race feminism, and relevant key concepts.

The purpose of this research is to give voice to, and a glimpse into the lived struggles, challenges, and successes that are experienced through the subjective lens of a black queer woman interacting within a complex social world. This research can offer rich insight into commonalities of experiences black women face in relation to experiences of erasure and silencing that live in various spaces. The aim of sharing the essence of lived events is to create bridges in genuine understanding and awareness about why black queer women are exposed to varying struggles that impact their experiences of pride and well-being. This research is being written from the position of resistance to traditional quantitative Western studies that have historically over researched and exploited those that are from my cultural identity. I deliberately aim to write this auto-ethnographic research from the heart with an insider perspective, to counteract the ways in which certain types of research are seen as credible. My hope is that this research will be accessible and relatable to members of various communities, regardless of their positionalities in this world. I seek to address the reality that literature often describes the experiences of black queer women from an analytical scientific perspective that focuses on existing health disparities, as opposed to their connections to existing structural oppressions. These forms of oppression manifest in various forms such as: substance abuse, mental health challenges, suicidal ideation, and varying violence within communities.

The direction of this paper is to go beyond merely listing the clinical definitions of risk factors that affect the health outcomes of black queer youth. I centre my experiences thus far in life, my interactions within various communities, and institutions. I want to put the spotlight on 
creating a visual that gives life to the ways in which the emotionality of pride and well-being are continual battles of survival and self-love that are rarely discussed from a non-scientific perspective of a black queer youth. Oftentimes black folks experience erasure from both communities as there is little space available where the presence of neo-colonial practices in queer and black spaces do not marginalize and divide the intersectional identities of black queer youth (McCready, 2004; Rwigema, Udegbe, \& Lewis-Peart, 2015). As a result, black queer youth struggle to figure out where it is that our selves can express authenticity in identity expression without fear of losing ties to our communities of origin. These communities live in various spaces that include but are not limited to: familial, racial, queer, and institutional forms.

Using a qualitative research design, I aim to fill in the gaps of knowledge in research regarding black queer women. There is little information present about how black queer women interpret and cope with various health struggles within the black and queer communities respectively. Battle and Defreece (2014) highlight a crucial lack in knowledge about what tools and values black lesbians use to determine their personal health and well-being outside of a traditional healthcare model. The research question used to guide the research will be: How does the erasure of the black queer female identity from the black and queer communities affect my experiences of pride and well-being? Exploring possibilities of answers to this question requires deep critical reflexivity going inwards as to comprehending how Western colonial systems of whiteness continue to infiltrate and result in the divisions that can be visibly seen and felt within the queer communities and black communities when intersections of race, sexuality, and gender come into play. 
I use auto-ethnography with the purpose of breaking the silence and giving voice to the everyday experiences of: anti-black sanism, heterosexism, anti-black racism, sexism, and homophobia that consistently shape my experiences in this world in relation to well-being and pride within the self. To counter the problematic issues of entering cultural communities, absorbing their epistemologies and taking it solely for personal benefit, I have decided to stand in solidarity with my communities by centering my own personal lived subjectivities. I believe every person can best speak to their own experiences. I want to acknowledge that as a black queer female within the educational institution, I am at a site of privilege where I have this opportunity to share my experiences and analyses; this is a privilege that many others within my communities do not have due to the existence of institutional barriers that create inequitable distribution of resources and information.

In Canada there continues to be an under resourcing and under funding of programs and initiatives that explicitly address the needs of queer and trans black people in a genuine inclusive way (Mullings, 2016). The experience thus far, is that our lived realities are often hidden from mainstream depictions and discussions as to what acceptable and welcomed queer bodies can be. Finally, I hope that this research can raise critical consciousness for those within the helping professions to gain a broader understanding as to the scope of what barriers black queer youth are up against and possibilities of interventions to create and support safer spaces. I hope that this provides black queer youth affirmation of their presence and lets you know that our black lives do matter; there are people who are fighting through shared traumas and struggles every single day that can help you on your journey to a path in life that brings you wellness and pride.

\section{$\underline{\text { Literature Review }}$}


This literature review will critically examine the present literature relative to my major research paper topic. The topic of this research is the intricate and complex experience of being a black queer woman. Through lived experience, I aim to go beyond present research regarding the complexity of this identity, by providing insight as to how systemic barriers affect personal experiences of pride and well-being as I transcend through spaces. The main purpose of pursuing this particular topic is to positively improve upon the existing epistemologies surrounding this marginalized community, in hopes that it can be used as a learning tool for those inside and outside of my communities. In respect to those within my community, I hope to provide information that resonates with them. The information might allow them to feel a strong sense of solidarity, and give language to recognize and provide guidance to resist similar experiences of oppression in their lives. Oftentimes the marginalized population that I am a part of has frequently been researched by those outside of the community. These researchers often bring only a limited lens of knowledges regarding black experiences, yet are published as recognized forms of scholarship. By critically analyzing a body of literature relative to this topic, I will seek to fill in the gaps of information using the self as a primary active tool to facilitate a conversation. I hope that this results in greater awareness, so that folks will be able to understand that the realities black queer women face are a result of the existing systemic barriers that serve to harm them in a multitude of ways. In the following section I will discuss the central themes found through a critical review of relevant literature. The themes are intersectionality, limited access to LGBTQ resources, performativity of gender and sexuality, and white supremacy upheld by anti-black racism.

\section{Intersectionality}


The first theme noted within the empirical studies reviewed would be that of intersectionality between race, gender, and sexuality as interconnected sites of oppression. This central theme reoccurred throughout the literature as an important aspect of how black queer females are perceived within society. It is impossible to view each piece of identity in isolation, if one seeks to adequately understand their everyday lived experiences in respect to marginalization (Carniol, 2000). According to Bowleg, Huang, Brooks, Black and Burkholder (2003) black lesbian women face a unique experience of multiple minority stressors from three distinct angles, which can result in ambiguous stress of uncertainty as it can be impossible to know if a stressor was due to racism, sexism, or heterosexism. Living in such a state of ambiguity can result in increased severity of overall stress, as these women are often unable to truly know what parts of their identities are being targeted.

Bowleg et al.'s (2003) study also brings in a crucial viewpoint when discussing the intersectionality of oppression, by engaging in conversations about the nature of their resiliencies in the face of adversity. The researchers found that the women were indeed resilient. Despite the minority stressors they faced, black lesbians harbor unique resources honed from previous experiences of sexism and racism. Bowleg et al.'s study attempts to add to the literature by allowing their participants to describe their active engagement with resiliency when facing a variety of difficult experiences. While outlining the various resiliencies of these women provide detailed insight into the acts of resistance that black lesbians enact when facing challenging situations, it can also be a problematic measure of knowledge in this context.

Carter and Little (2007) describe how epistemology within qualitative research is theoretical; every research adopts a theory in relation to knowledge because an understanding of 
its essence and how it is formed is necessary in furthering the creation of new knowledges. Although the findings of the Bowleg et al. (2003) study do suggest resiliency is embodied in these women as they face various minority stressors, one must look at the context of where the knowledge was produced. The study purposefully recruited black lesbian women from a retreat aimed at celebrating their identities; therefore, the validity of the study remains questionable. The strategic selection of black lesbian women that were willing to disclose their identities, as well as publicly celebrate them implies a degree of comfort. This study is limited in scope due to the black lesbians selected because it allows for inherent sampling bias to have taken place. It can lead to misleading assumptions for readers, who may presume that the issues black women face are relatively benign, if they are all able to consistently experience resiliency. Many black lesbians and their experiences of resiliency are excluded. There can be various reasons as to why black lesbian women would not wish to celebrate their identities at a public event. However, this does not mean that they are not as resilient in a multitude of ways as the women who would go to the celebratory retreat.

In relation to the Bowleg et al. (2003) study, another was done that addressed the major theme of intersectionality of identities. Bowleg, Craig and Burkholder (2004) conducted a qualitative study exploring what factors predicted active coping amongst black lesbians in a sociocultural context assessing: racism, sexism, and heterosexism. This study comprehensively distinguished internal factors within the self-such as: sexual orientation identification, racial identification, and self-esteem from external factors such as social supports and availability of LGBT resources (Bowleg, Craig, \& Burkholder, 2004). The findings in the sample of black 
lesbians illustrate how imperative self-identification is in respect to the adaptation of healthy coping mechanisms.

I argue that although the Bowleg, Craig and Burkholder (2004) study is of value, it is greatly problematic given the sample of black lesbians that were chosen. This study can also be viewed as exclusionary because black lesbians possessing class privilege and higher education were solely included. In respect to resiliency this is highly problematic, because those who have access to greater resources and opportunities may be better able to access internal and external coping mechanisms (Bowleg, Craig, \& Burkholder, 2004). This study fails to adequately explore the varied experiences of black queer women who do not easily have access to external supports or the luxury of attending celebratory retreats. This study raises important gaps relative to my research as it acknowledges the lack of empirical focus on the extent to which external traditional black factors such as, familial values, black churches, and spirituality, hinder or aid black LGBT groups in coping with stressful life occurrences (Bowleg, Craig, \& Burkholder, 2004).

Another research study that centers intersectionality as a major theme was conducted by Hsieh and Ruther (2016). This particular study took an intersectional approach to explore how available healthcare access and certain behavioral risks contribute to health disparities of those who are of minority gender, race, and sexual orientation (Hsieh \& Ruther, 2016). In respect to sexual identity, this study fails to broaden its exploration of those who do express same-sex attraction and behaviors, yet do not necessarily identify as a sexual minority (Hsieh \& Ruther, 2016). This is problematic because the study is intended to be intersectional. For this reason, the heterogeneity of sexuality beyond sexual identity should be addressed further to ensure the 
health experiences of all sexual minorities are taken into account to produce greater validity within the study.

The Hsieh and Ruther (2016) study effectively highlights the privilege inherent in whites, particularly straight males who consistently experience better health outcomes than all sexual minorities including black queer women (Hsieh \& Ruther, 2016). This study emphasizes that although black lesbians may be disadvantaged in at least three salient different ways (race, gender, and sexuality), this does not necessarily mean they will always fare worse in comparison to other disadvantaged identities (Hsieh \& Ruther, 2016). This can be explicitly linked to the resilience theory that black women use to manage the health consequences they may face stemming from their embodied self (Hsieh \& Ruther, 2016). The outcomes of health and experiences of black lesbian women must be evaluated through an interpretive paradigm, as every shared identity will not necessarily experience the same risk factors and health disparities. An interpretative paradigm is premised on the notion that there can be multiple truths that are socially constructed, and every person has a unique reality they experience shaped by their own positionality in this world (Willis \& Jost, 2007).

\section{Limited access to LGBTQ resources}

Another reoccurring theme within the literature would be that of the limited participation and accessing of general LGBT resources in relation to black queer people. In a study conducted by Rosario, Schrimshaw and Hunter (2004), they found that black queer youth were less involved in LGBT related community activities in contrast to their white counterparts. The youth in this study also expressed greater discomfort in disclosing their identities to others. Rosario, 
Schrimshaw and Hunter (2004) reveal that "after initial involvement, Black queer youths may retreat from gay-related social activities in the LGB community, perhaps because of racism in the LGBTQ community" (p. 225). As black queers, race is salient when entering mainstream queer spaces, which are often designed under a lens of whiteness. This article effectively relates to the research I conducted through critical reflexivity of analyzing my experiences with the mainstream queer community. This study will aid in the exploration of my research question because as a youth, I would continually lack participation within various queer activities due to continual feelings of discomfort in those spaces.

Another empirical research study conducted by Lopez, Antoni, Fekete and Penedo (2012) found a lack of participation by HIV positive minority women in accessing resources within their communities. Lopez et al. (2012) indicate how ethnic identity facilitates racialized women's access to social supports and resources in their community that they may have been unaware of, and promoting healthy coping strategies to improve their quality of life. This article resonates with the previous study regarding the avoidance and lack of accessing social supports for black identified queers. When questioning why these women may have been hesitant to access these resources, this again might be related to the overall functioning of whiteness within dominant spaces that can create an unwelcoming atmosphere for black queer women.

I suspect that many of these women noted in the Lopez et al. (2012) study, such as the black queer youth, may feel discomfort in entering these spaces where their multiplicity of identities is not adequately acknowledged. Lopez et al. (2012) critically highlight future recommendations for related research of sociocultural factors such as acculturation and value systems that influence minorities' experiences of health and well-being (Lopez et al., 2012). This 
article raised an interesting point about how rates of acculturation to the dominant culture could have serious impacts on the decisions made by black queers to access resources in the LGBT communities and black communities. I suspect that the well-being of black queer women suffers when there are higher instances of acculturation experienced within Western culture. It is well known that black women face various sites of stigma that shape their experiences, and the necessity of advocating for health and well-being is connected to accessing communities. Acculturation can have negative effects on authentic identity expressions, as there is consistent societal pressure for black folks to conform to unrealistic standards of white nationalism that can cause internal struggles through internalization of oppression and decreased self-worth. Lopez et al. (2012) state that "interventions that are tailored to the cultural and social environment of WLWH (Women living with HIV) and which teach them how to access resources available in these contexts may have lasting impact on stress, quality of life, and health outcomes" (p. 27). In conclusion, an intersectional response is required from social institutions that should focus on creative ways to invite and welcome black queer youth by listening to their needs and experiences. Interventions that are reflective and respect the complexity of black queer youth will lead to lasting positive outcomes for their communities.

Performativity of sexuality and gender Another theme in the literature pertains to the performativity of sexuality and gender. In a study conducted by Mollen and Stabb (2010) they describe how the women within the study explained that many struggled with sexual suppression of their identities and the performance of sexuality to please those around them; rather than engaging in sexual experiences with their pleasure as a point of focus. This study follows how women interrogate their ways of being and come to question their sexuality, moving from 
suppression to a reclaiming of sexual expression and ambiguity. This study effectively highlighted how female gender performativity and sexuality can be restrictive and oppressive, particularly for some women who do not feel that their understandings of sexuality can be accurately captured under simplistic labels. This study was unique because it allowed women to reimagine and explain the complexity of sexuality through various metaphors that allowed them to use creativity to learn about themselves. A limitation present within the structure of this study would be the lack of diversity in regards to the women selected. I would suggest that the representation of trans women be included as this study attempts to capture diversity of sexual meaning making, yet these voices are not heard. This study also lacks racial diversity as a majority of the women participating were white. Therefore, detailed subjectivities of black women and other races were absent from central discussions in the small sample.

In relation to gender, there are nuances as to what performativity can mean for different people, as well as what it can feel like, and why it is enacted in a particular manner. I understand performativity of gender as an enactment, that can have dramatical aspects, yet it is not always necessary. The reproduction and appearance of adhering to binary norms are rewarded by dominant society, while precarity can come from rejecting, and reframing gender expression and norms. According to Butler (2009) gender performativity is:

a certain kind of enactment; the "appearance" of gender is often mistaken as a sign of its internal or inherent truth; gender is prompted by obligatory norms to be one gender or the other (usually within a strictly binary frame), and the reproduction of gender is thus always a negotiation with power; and finally, there is no gender without this reproduction 
of norms that risks undoing or redoing the norm in unexpected ways, thus opening up the possibility of a remaking of gendered reality along new lines. (p. 1)

Another article that touches upon the complex concept of gender and female sexuality was related to LBQ Latinas and their families. This study uses a dramaturgical framework to analyze human social interactions as they are understood to resemble the essence of performances; people play socially expected roles based on their unique positionalities within the world. Acosta (2010) found that these women go through deliberate strategies of conformity and non-disclosure when presenting the self to their families to minimize the risk of rejection and shame. These performances include pretending to have relationships with male friends to please their families (Acosta, 2010). Acosta (2010) touches on the performativity of gender and sexuality as it manifests in the presence of pervasive heteronormative values and expectations within their families. The participants expressed that they received the strongest resistance to their sexual orientations from their mothers, who viewed their disclosure as a reflection of their parenting styles, as well as a failure in the teaching of cultural heterosexuality (Acosta, 2010). In contrast to all other family members, Acosta (2010) found that the member that most disapproved of their sexual identity were their mothers. Cross culturally women have historically mainly been responsible for taking care of their children. This care includes traditional gender roles and sexuality expression that are often taught by women in the family, primarily mothers. This research reveals that there continues to be struggles of familial acceptance in regards to the authentic identities of LBQ Latinas, as they try to find space to express themselves while negotiating belonging in the structures of their communities and families. 
This particular theme of performativity of sexuality and gender resonates with my MRP topic as my relatives on my mother's side are Afro-Colombian immigrants to Canada. Even when these women and their families are no longer within their South-American country of origin, the cultural values and traditions continue to persist in respect to expectations of heterosexuality and femininity placed upon their daughters. A gap in this research that I am interested in exploring would be that of hearing the subjective voices of the mothers' of LBQ Latinas. Acosta (2010) notes that a major limitation within her study was there was not a focus on the relatives' experiences of their sexual disclosure and their rationality for engaging in various strategies of avoidance. I intend on exploring this avenue through my qualitative research reflecting on transformative pieces where I have also had to endure the performativity of sexuality due to the fear of rejection and risks of negotiating disclosure in my Black-Latino upbringing.

\section{White supremacy upheld by anti-black racism}

A key theme within the literature is the presence of anti-black racism and its direct connection to the complex system of whiteness. In her doctoral thesis 'The black Jamaican criminal: The making of ideology' Benjamin (2005) critically addresses how whiteness functions within various social and cultural institutions to continually create and perpetuate black Jamaicans as inherently deviant outlaws in a Canadian context. Benjamin (2005) states:

The dialectic in Whiteness depends on the subordination of Blacks and other peoples of colour. For such populations must be made amenable to White systems of governance 
and domination, through processes of enculturation and assimilation. This process is often entered into unconsciously and without benefit of choice. (p. 11)

The existence and functionality of whiteness is dependent upon the subordination of black and other racialized peoples, as these groups are targeted to be managed and controlled through violent mechanisms. This revelation resonates with me, as I am now able to recognize and give name as to why my family, who are immigrants from Kingston, Jamaica continue to be labelled by the majority as a problem population that need to be feared. In my research I will describe moments where I did not realize I was unknowingly accepting the enforced systems of white supremacy that policed and harmed my black body in many ways.

A key topic within the literature to discuss is that of the ongoing relationship of homophobia and colonialism in a Jamaican context. King (2006) states:

The contemporary Jamaican experience is one built on servitude and exploitation. The Indigenous Arawak population was decimated by Spanish and British colonizers, thus the foundation for contemporary Jamaican society was really laid in 1655 when British settlers, consisting mainly of prisoners and people in political exile, began trafficking African slaves to the island. Under this system of legalized slavery, Jamaica became Britain's most prosperous colony. (p. 17)

In mainstream Canadian society, I consistently hear many folks framing Jamaica as one of the most homophobic places that exists in the world. As a black queer youth, this is a consistent message that I would hear from those within and outside of my communities, as Jamaica was viewed as a place that was dangerous and unsafe especially for queer people. 
Growing up in a predominately white area, I simply accepted that the island of my origins was simply not as progressive as other countries such as Canada. As an older youth, I have become equipped with access and agency to critically investigate why Jamaica is viewed by the majority as a place that black queers should fear. I internalized this messaging without questioning their sources as they were phrased as objective truths about the history of my ancestors. King (2006) outlines "Most, however, believed that homosexuality was a western imposition introduced to people of African descent during slavery and, thus, a disgrace to the black race, a symbolic reminder of 400 years of servitude and sexual exploitation" (p. 26). The domination and harmful impact of colonization of the mind is evident as internalized homophobia is met with shame and guilt. What was hidden from the learning I received was the Euro-centric curriculum and its forced adoption of Western beliefs and values about sexuality.

Homosexuality prior to colonial contact, I imagine was accepted and respected as lived realities that simply coexist. The universality of heterosexuality becomes challenging to defend when there is the existence of North American Indigenous people who have flourished in gender and sexually diverse realities for generations (Alears, 2010). On the gender continuum, in Indigenous communities Two-Spirit people face the enforcement and coercion of adopting Christian, heterosexist, and homophobic beliefs; in addition they experience immense challenges as a result of the erosion and at times elimination of various traditions, teachings, and languages (Baskin, 2016). The link between the ongoing negative impacts of colonization on Indigenous people in Canada and on a global scale is a clear mechanism of white supremacy that must be dismantled through action. I believe an alternative world is possible, where the power of white 
supremacy ceases to exist; where QTBIPOC people are respected and treated with genuine equity through unified efforts of decolonization.

\section{White settler colonialism and queer politics}

Another important research study investigates the impact that white settler colonialism and homonationalism has on queer politics in Toronto. Greensmith \& Giwa (2013) state that "the superficial inclusion of two spiritedness within LGBTTIQQ2S culture and politics masks the ongoing settler-colonial violence required for modern queer formations to exist” (p. 2). This declaration highlights the inherent injustice present, where white settler sexuality is normalized and Indigenous subjectivities are entirely displaced from focus. This study utilizes a decolonizing framework as a form of resistance to traditional studies with Indigenous peoples. Puar (2007) defines homonationalism as the existence of modernity and a historical shift distinguished by the appearance of certain queer bodies as deserving to be protected by nations, a concrete transformation of the connections between capitalism, the nation, and sexualities (p. 337). Historically white settlers have been the main subjects who represent queerness through the initiatives of homonationalism in effect along with various neoliberal strategies that portray Pride Toronto as an all-inclusive space when this is merely an illusion. In regards to the knowledges constructed at Pride Toronto, Indigenous perspectives are often appropriated and misrepresented if at all mentioned. This has consequently impacted the ability for true social justice and positive change to occur because many white settlers and racialized settlers on this land are reluctant to acknowledge their role and complicity in the continual oppression and erasure of Indigenous bodies from participation in the formation of queer politics. To dismantle the forces of homonationalism requires a decolonizing framework where Pride Toronto retakes a political 
stance. Rather than being focused on privatized consumption there must be a centering of Indigenous epistemologies, providing the freedom for all expressions of gender and sexuality.

The Canadian state undeniably gains benefits of capital through the ways in which LGBTQ concerns and rights are addressed. Eng (2010) highlights how queer liberalism is disguised as progress, and self-determination connected to the notion of ideal citizenship; there is a violation of forgetting at the core of queer liberalism's legal success to reinstate conventional formations of family and bonds (p. 25). This speaks to the reality that queer folks have had to fight for various citizenship rights that are given by virtue to heterosexual cisgender people. This fight is strategic under the premise of queer liberalism that gives off an illusion that real progress is occurring when queer people are able to finally obtain marriage, adoption, and citizenship as long as it aligns with heteronormativity. Eng (2010) describes a historical shift where queers who once radically critiqued heteronormative state notions of family and bonds, are now fighting for state legitimacy and privileges attached to social institutions such as marriage and adoption. This contradictory shift is not merely a coincidence, but the aim of queer liberalism is to control and maintain power over queer lives, while giving an appearance of growing to be more progressive by shifting societal attitudes towards queer people.

\section{Psychological distress and acts of heterosexist discrimination}

Another significant theme within the literature would be the relationship between psychological distress and acts of heterosexist discrimination. Due to the multiplicity of salient identities that black queer women possess, this creates exposure within the social world to various acts of discrimination that have serious impacts on their overall health in a variety of 
areas. Increased instances of discriminative events related to the persistence of heterosexism, can have lasting effects in the form of internalization. Symanski and Chung (2001) report that internalized homophobia consists of various dimensions: a relation to the lesbian community, self-identification as a lesbian, sentiments about being a lesbian, and sentiments about other lesbians. The study was conducted using a large sample of lesbian female participants. The results of Symanski and Chung's (2001) study found a concise correlation of higher rates of internalized homophobia being associated with increased forms of psychological distress. The implications of this article are important to the construction of knowledge regarding the internalization of homophobia as this is a direct product of the heterosexist society that queer individuals must navigate. This research study by Symanski and Chung (2001) utilized an efficient scale which asked questions such as "social situations with other lesbians make me uncomfortable" (p. 45) that could also be applied to different community or health care organizations that are seeking to assist lesbian clients in constructively managing psychological distress, including internalized homophobia. Although helpful, this study lacks diversity in regards to the participants chosen. The participants in this study are lesbian identified women, however, the diversity within this category are not adequately represented in regards to race, ethnicity, and socio economic backgrounds. Therefore, the information that has been presented cannot possess external validity as the experiences of racialized and Indigenous women have not been appropriately examined.

The following research study highlights how the social environment and present heterosexist climate must be considered, when understanding why queer women experience an array of symptoms which manifests as distress. This study focuses on incidences of expressed 
psychological distress and forms of heterosexism that lesbian women face. Through a feminist theory perspective, Symanski (2006) found that perceived or real heterosexist stressors have negative impacts on the mental health and well-being of lesbian women. This study provides detailed data suggesting the presence and variation of heterosexism, yet the scope of this is limited to individual accounts. This study offers valuable direction for future research by suggesting that exposure to heterosexist practices at institutional and cultural levels should also be addressed (Symanski, 2006). By evaluating these larger instances of heterosexism and their impacts on the psychosocial health of lesbian women, necessary progressive action can take place to improve the well-being and confidence of lesbian women.

Additionally, another study emphasizes the importance of focusing on the relationality of psychological distress and acts of heterosexist discrimination. Fingerhut, Peplau, and Ghavami (2005) utilized a dual identity framework to analyze how participation in the dominant heterosexual world and the lesbian minority world, are related to experiences of discrimination and feelings of internalized homophobia as a form of stress. This study is effective in capturing the complexity surrounding the sentiments of internalized homophobia; women who were greatly involved in the lesbian community revealed an increased frequency in discrimination throughout their lives (Fingerhut, Peplau, \& Ghavami, 2005). This study begins an interesting dialogue surrounding the connectivity of lesbian identification within both social worlds and the negative impacts this can have as women are exposed to heterosexism. However, this study fails to begin to question how women who may not openly express their sexual orientation are likely to experience internalized homophobia and heterosexism in different ways. 
A limitation to the Fingerhut et al. (2005) study is there is a lack of lesbian women's voices as a central focus in the research. Another area of critique for this study would be a lack of deeper analysis of the intersectionality inherent in the lives of racialized women and their experiences of psychological distress as a result of various forms of oppression, especially racism. There is an absence of these knowledges being introduced in-depth, as their experiences of internalized homophobia will likely be unique due to the experiences of racism that affects their interactions within and between both the lesbian and heterosexual dominant culture. Consequently, continual experiences of racism can result in the isolation of these women as they find little space to experience safety and belonging. This study highlights the reality that there continues to be the erasure of black queer women's subjectivities. When these women are mentioned within studies, they are usually discussed in passing, yet their experiences are never centered alongside their white counterparts.

In relation to the previous theme, a research study by Lehavot and Simoni (2011) took a step further by exploring psychological stress and the various effects on sexual minorities. This study is unique as it actively measured the role of gender expression in relation to instances of psychological stress experienced by participants. Lehavot and Simoni (2011) discovered that gender expressions of masculinity were associated with increased reports of discrimination, yet resulted in less internalized homophobia or attempts to conceal lesbian identities. These findings suggest that there is indeed a need for healthcare professionals working with lesbian women to assess gender expression as a variable that carries very different experiences of discrimination and internalized homophobia. In contrast women within this study who had more feminine 
expressions were noted to experience greater internalization of homophobia and concealment attempts (Lehavot \& Simoni, 2011).

The findings of Lehavot and Simoni (2011) are important to consider when conducting my research as they introduce the variability in experiences of discrimination in the social world. As a queer woman who presents as androgynous, I begin to critically question how this affects the way institutions and others within a heterosexual society view my body in various spaces. I am often presumed to be heterosexual. In the mainstream queer community, I would be read as an individual that has an aura of passivity. As a result, this has great implications for how black queer women, depending on their gender identities and expressions will experience, different degrees of challenges in regards to their sense of pride and well-being.

Lastly, a fascinating study focusing on lesbians and their sisters that were heterosexual, interrogated what contributes to differences in demographics. These variations in demographics are explored in relation to differences in health outcomes and opportunities available. This study is innovative as it uses heterosexual women to highlight the distinct differences in lesbian women to gain a better understanding of the complexity of these women's lives. A surprising finding was that lesbian women were found to experience higher levels of self-esteem in comparison to their heterosexual sisters (Rothblum \& Factor, 2001). This finding can be considered rather puzzling because the identity of lesbian is a stigmatized one in a broader heteronormative society. Rothblum and Factor (2001) propose that lesbians have ventured away from rural areas to urban spaces, where they are able to find greater supportive spaces and opportunities to openly express their identities. Further research should be directed to explore the correlations between higher self-esteem rates in lesbian women in comparison to their 
heterosexual sisters. This study acknowledges that the missing voices and experiences of bisexual women have not been analyzed in regards to their knowledge creation. However, this study recommends that future research on bisexual women be conducted, as they are a population that experience increased risks for mental health challenges; even when various demographic factors are controlled (Rothblum \& Factor, 2001). An important limitation to note within this study is that it runs the risk of essentializing identities into particular fixed categories of heterosexual and lesbian implying little possibilities for change, as opposed to speaking about gender and sexuality from a more fluid subjective stance.

The literature review has greatly increased my overall knowledge regarding the erasure of black queer women and their multiple experiences in respect to well-being and belonging within society. These empirical studies have provided rich findings that suggest that more qualitative research needs to be conducted that centralizes the subjectivities and knowledges of black queer women as they navigate the black and queer communities. It is evident that embodying a multiplicity of complex identities has direct challenges these women face in regards to overall health outcomes and opportunities in life. As a researcher I aim to critically interrogate the knowledges that exist within these bodies of literature. I aim to alter the conversation by examining how the systemic erasure that persists upon black queer bodies greatly impacts health outcomes and the quality of life from a deeply personal perspective. The research I will conduct will be transformative through the process and outcome for me. I hope to further reflect on these themes fleshed from the literature, as they will be valuable markers as to where my subjugated knowledge can exist.

\section{Theoretical Framework}


In this section, I will outline and describe my theoretical framework as well as my rationale for using them as a lens to conduct my auto-ethnographic research. My theoretical framework is based on two theories which are queer theory and critical race feminism. I will begin by defining my framework, then discussing why I have chosen them as they align with my own ways of being, knowing, and values as I travel on my path. The approach of poststructuralism informs my choice of theoretical frameworks as they take on a stance of subjectivity regarding epistemologies as opposed to a lens of objectivity when analyzing the dynamic social world. The theoretical framework I have chosen will be discussed in-depth as they inform embodied epistemology, ontology, and axiology throughout the research process.

Although queer theory is an effective theory to guide my research in respect to possibilities and fluidity, it is important to outline its shortcomings that are noted by queer and transgender black Indigenous and people of color (QTBIPOC). Jasbir Puar (2007) discusses neoliberalism in the context of homonationalism where white queers are viewed as worthy of state protection and privileges under the guise of white supremacy and freedoms while others are not granted this treatment (p. 337). Queer theory has been noted by scholars such as Puar (2007) for its failure to address and discuss Islamophobia, settler colonialism, and white supremacy specifically in its formation. By using critical race feminism, I aim to go further as it effectively addresses intersectionality, and focuses on the areas above that queer theory has not traditionally deeply engaged with.

\section{$\underline{\text { Critical Race Feminism }}$}


To begin to understand the emergence of critical race feminism it is imperative that one gains a comprehensive understanding of its origins. Critical race feminism was born out of critical race theory in the 1970s (Razack, Smith \& Thobani, 2010; Wings \& Willis, 1999). Critical race theory was formed out of the desire to critically interrogate and formulate approaches that address the ongoing power relationships between the following: white privilege, racism, and discrimination within the legal systems that govern people of colour (Wing \& Willis, 1999). Critical race theory sparked ground breaking discussion about whiteness, and the relationship between state sanctioned anti-black racism, and violence against black peoples. Williams (2016) speaks of whiteness as framed under a guise of normalcy and complicity, where it is presumed to not be a real racial identity, it is defined as having no colour, in relation to blacks that live in another world and location separate from whites, so their whiteness remains unnamed and their privilege intact. Critical race theory also prioritized the sharing of narratives or story-telling as a means to understand and address racial oppression. Essentially, critical race feminism goes further by identifying that critical race theory fails to accurately address the powerful role that gender and race can play in varying the experiences of black people as they interact with various spaces and institutions. Wing and Willis (1999) state that "critical race feminists focus on the intersection of race and gender, emphasizing the anti-essentialist premise that women of colour are not simply white women with the added factor of race or men of color with the added factor of gender" (p. 3). I intentionally chose critical race feminism because I want to move away from the reality where black peoples are often essentialized as having the same lived realities without the consideration of gender identities. Countering this essentializing, 
Crenshaw (1989) coins the term of intersectionality of race and gender through this powerful analogy:

Consider an analogy to traffic in an intersection, coming and going in all four directions. Discrimination, like traffic through an intersection, may flow in one direction, and it may flow in another. If an accident happens in an intersection, it can be caused by cars traveling from any number of directions and, sometimes, from all of them. Similarly, if a Black woman is harmed because she is in an intersection, her injury could result from sex discrimination or race discrimination... But it is not always easy to reconstruct an accident: Sometimes the skid marks and the injuries simply indicate that they occurred simultaneously, frustrating efforts to determine which driver caused the harm. (p. 149) It can be difficult to internally decipher what exactly caused the harms I experience at times when an incident occurs, because there are many sites of possible discrimination; for example, in addition to the above, my sexuality becomes another target of discrimination within society, that can also happen simultaneously and in a linear manner.

As a black female, my positionality in the world is vastly different than the struggles of other gender identities, because of the realities of misogynoir, and sexism that constantly affect the way I am perceived and treated as a black person through various institutions and communities. Misogynoir is a term coined by Moya Bailey (2010) to describe the reality of discrimination and prejudice against black women intersecting with sexism and race. This framework centers the experiences of racialized women as undeniably unique, as opposed to previous traditional waves of white feminism that put the lived realities of black women on the margins of feminist activities. Through the movement of mainstream feminism, there was a 
continual assumption that the struggles and triumphs that white women gained were the same for black women. The emergence of critical race feminism in the 1990s is a powerful framework that takes an anti-essentialist stance, where my femaleness and blackness are intersectional identities that have shaped the ways in which queer communities, black communities, and broader institutions respond to my existence.

Childers-McKee and Hytten (2015) describe the potential of critical race feminism to explore social phenomena from the standpoint of folks that are marginalized by race and gender; arguing that it builds on CRT by adding an intersectional gendered perspective to explore social justice efforts within a school context (p. 395). Childers-McKee and Hytten pose an excellent point that CRF can effectively be utilized by various educators to critically analyze the multiplicity of ways in which educational institutions create and perpetuate inequity and oppression under the false notion of a meritocracy. This framework accurately highlights the pervasiveness of whiteness and its manifestations through oppressive curricula, practices, and standardized forms of evaluation that limit possibilities for genuine self-expression and discussion of alternative non-white realities.

To counteract mainstream narratives about the experiences of a black identity, I have carefully selected critical race feminism. However, I must note that this theory is parallel to the outstanding work that has been done by racialized folks who use the critical perspective of black feminism as a lens to inform and guide black experiences. I have chosen critical race feminism to purposely critically decolonize my own mind, and experiences of growth and struggle navigating through my own identity as a child of immigrants to Canada. According to Few (2007), "both theories emphasize the intrinsic and authentic value of racial/and or ethnic scholarship in 
representing the lives of groups of which researchers are a part" (p. 457). This theory provides an alternative lens that shifts away from whiteness and sexism by emphasizing that racialized researchers can offer great value to academia by representing their communities in ways that are accurate and liberating. Through storytelling of lived experiences, I will explain how I came to internalize and believe that I could never be a scholar; accepting that my people could be researched ethically by white peoples. Embodying the identity of black and female within a society where I am viewed as the "other" because of my appearance has a key connection to continual struggles of embracing self-worth. As a female, beginning with the institution of family, I was raised in cultures where the oppression manifested itself in pressures to conform to expected heteronormative gender roles.

As a youth, I had failed to recognize the connection between colonization and expectations placed upon me through the system of patriarchy within Latino and Caribbean cultures. The imposed Euro-centric values and ways of thinking being placed upon my peoples in the past and present prioritized binaries and separateness in all parts of life. The invasion of Euro-Western peoples into the Caribbean and South America has had detrimental impacts through the enforcement of heterosexuality, male privilege, and female inferiority. By using critical race feminism, I actively seek to resist this experience of separateness and bridge all parts of who I am because separately they cannot be understood nor embraced with pride. Critical race feminism is strong at analyzing the reality of settler colonialism and its implications for racialized and Indigenous women in a Canadian context. Critical race feminism deconstructs the complexity of race and immigration of racialized newcomers to Canada (Pon, Gosine, \& Phillips, 2011). Critical race feminism highlights that they are also implicated and complicit in the 
perpetuation of colonialism against Indigenous Peoples, particularly women. Razack, Smith, and Thobani (2010) state,

In the climate of a rising neo-conservative politics in the last decade of the twentieth century, and an increasing overt hostility towards the "burden" placed by immigrants and refugees on "national" resources, the decision of the Canadian government to participate in the War on Terror presented significant challenges to the work of Indigenous and critical race feminists" (p. 4).

Critical race feminism does an excellent job of deconstructing the myth of Canada as a nation of peacemaking. Indigenous, black, and brown bodies in Canada are all negatively impacted by settler colonialism and Islamophobia in harmful ways. Using this framework emphasizes the unsettling of settler colonialism in a Canadian context where my experiences as a black queer person must be reflected upon, recognizing how I do benefit as a settler on Indigenous land from the state harms that continue to be enacted disguised as multicultural narratives and newcomer policies.

\section{Queer Theory}

The first interpretative theory to gain a greater understanding of my topic I have decided to use would be that of queer theory. This framework aligns with my ontology or way of being in the social world, as it is gives voice to my experience through my queer body. Additionally, this theory embodies within its axiology, the values of: positionality, fluid realities, instability, and non-conformity. Queer theory critically explores how particular identities are consistently performed and reproduced, deliberately challenging notions of normalcy and rigid binary 
categorizations of populations (Creswell, 2007; Eng, 2010; Muñoz, 2009; Poon, 2006; Puar, 2007; Shraya, 2013). This theory opens up possibilities to comprehending culturally dominant views of sexuality and gender; as well as how they impact those who become viewed as deviating from expected identity expressions within their cultures. Using a queer lens, my research will aim to address the discourse of homonormativity. Kacere (2015) explains "Homonormativity is a word that addresses the problems of privilege we see in the queer community today as they intersect with white privilege, capitalism, sexism, transmisogyny, and cissexism, all of which end up leaving many people out of the movement toward greater sexual freedom and equality" (para. 2). Homonormativity often goes unnoticed by those who gain unearned benefits within the queer community, also within our broader heteronormative society. This phenomenon of invisibility to those with power is directly related to the institutional functionality and normalcy of whiteness. Kacere (2015) notes this in the following: "Homonormativity explains how certain aspects of the queer community can perpetuate assumptions, values, and behaviors that hurt and marginalize many folks within this community, as well as those with whom the community should be working in solidarity" (para. 5). The work towards solidarity with QTIBIPOC communities is one that is ridden with tensions, where some white queers are resistant in wanting liberation and freedom for QTBIPOC people as this involves a forfeiting and naming of how they are complicit and benefit through the harms enacted upon us, as well as doing the work of showing up to support our communities in ways that work. In Toronto, there continues to be tensions as white queer histories and stories are prioritized under homonationalism that continues to perpetuate the erasure of racialized and 
indigenous QTBIPOC histories, resistance, and activism who built the movement, who have always existed and continue to do this work (Ware, 2017).

I intend to share my story as a form of resistance to the continual historical and present denial of my existence as a black queer person who continues to engage in storytelling, sharing, and supporting those within my communities in resisting the erasure and denial of our identities. Queer black female bodies are a group of those people who receive little positive representation in history, archives, and mainstream media. It is important that this normality of invisibility is disrupted through questioning how the expressions of queer white people within our capitalist society, receive a surplus of benefits for behaviors that mirror heteronormative gender and sexuality performance. For example, the movement to legalize gay marriage perpetuates and centers portrayals of nuclear married families consisting of white gay men. There needs to be efforts to counteract the damaging effects of homonormativity, as it forcefully provides little space for queer black bodies to experience a sense of identity pride and safety within their communities. Queer theory helps to provide the foundation to begin to explore why even in queer spaces, as a black person I have felt unwelcomed and viewed as the undesirable type of queer due to my blackness, gender identity, and sexual orientation.

Through their critical deconstruction of queer space, Oswin (2008) argues "that in queer space there is importance in their acknowledgment and dismantling of the homosexual/heterosexual divide yet other binaries hang on such as: masculine/feminine, racialized/white, high class/low class" (p. 96). As a black racialized queer, I have and continue to experience many queer spaces that claim to be inclusive and progressive such as the mainstream Church and Wellesley Gay Village. There continues to be a higher presence of cissexual gay 
white males in all spaces. As a result, I face ongoing struggles as I question the agendas of these corporatized spaces that claim to be for everyone on and beyond the LGBQT spectrum. It becomes clear that white privilege relies on the division of racialized queers from whites, and the inaction of white queers in the naming as well as organizing against anti-black racism in solidarity for racial justice. Queer theory informs my journey throughout life as it is inherently exploratory and critically challenging of binaries, static ways of thinking, and being across a range of realities and spaces.

As Browne and Nash (2010) assert that "Queer scholarship, then, in its contemporary form is anti-normative and seeks to subvert, challenge and critique a host of taken for granted 'stabilities' in our social lives" (p. 7). There is a sense of comfort and security when human beings are able to efficiently categorize and label people based on a set of attributes for easy processing. Queer theory seeks to contest norms and critique how these have come to be and the agendas they serve, as well as who benefits from the maintenance of social categories. Personally, queer gives space to embrace and explore my gender identity, expression, and sexuality. Although I identify as a non-heterosexual, and as a woman, I identify with queerness as a form of resistance to be able to freely explore identity living outside of enforced heterosexist expectations. When I began to realize as a youth, that I was same gender loving, I began to receive pressure from those in my life to prove through behaviours that I truly was what it meant to be the opposite of heterosexual - a lesbian. In my youth, I equated feelings of same-sex intimacy and attraction as only belonging to the socially constructed term of lesbian.

Therefore, I grew up most of my life trying to measure up and prove to those around me that I was not pretending. Due to my femme appearance, folks in my life would continually 
question whether I was a 'real' lesbian. However, as I grew older I realized that the term lesbian did not fully encompass who I am in relation to gender, sexuality, and attraction; it did not do justice. I realize that queer is a term that I personally reclaim, as it stresses the existence of impermanence and the openness to change. I have come to embrace that I am not only cisgender attracted, as there are various transgender and non-binary identities that I feel attraction towards. Queer theory gives perspective to the vitality of fluidity and instability in our social lives as this evokes unrestrained authentic expressions of the self that facilitate health and well-being.

As a young racialized queer scholar, using queer theory from my subjective perspective is an action itself that interrupts, reimagines, and expands on key contemporary social issues in a Canadian context. Since its beginnings, queer theory has primarily focused on the subjective stories, experiences, and histories of white queers where the insights and concerns of QTBIPOC scholars in various spaces have been met with resistance. Presently, the most innovative noteworthy works on queer theory is led by QTBIPOC scholars who are paving the way where new critical discourses, stories, and knowledges are celebrated and shared to strengthen intersectional understanding and learning within queer pedagogy. Queer theory is now addressing and critiquing complex social issues as it grows in scope including but not limited to: the diaspora, transnationalism, citizenship, the racialization and criminalization of QTBIPOC people (Eng, Halbertstam, \& Muñoz, 2005). The future of queer theory looks much more critical, intersectional, and transformative than ever before; the aim of using queer theory is to support my reality, as well as to further add to the scholarship.

\section{Methodology}


The methodology I have chosen for my proposed topic is auto-ethnography. Adams and Manning (2015) describe a key belief of auto-ethnography is that culture is interpersonal and circulating through the self; an individual is never existing apart from cultural affects with other human beings. In relation to auto-ethnographic research, they reveal the reality that research cannot be conducted on individuals with neutrality, as people are relational beings and no one can be immune to the influences that relationships have on our experiences in a social world. For the topic chosen, I know that it is impossible to conduct research on black queer female youth without my own personal experiences, beliefs, and assumptions impacting the way I would engage with this group. Instead, I choose to integrate and share the experiences I have had as this is an opportunity for personal growth and healing, and awareness as well as an offering of information to readers. I do acknowledge the difficulty for me in the process of auto-ethnography as it can reopen painful wounds manifested in memories and analyses. However, I have strategically chosen auto-ethnography as it seeks to critically interrogate past personal experiences relative to a specific cultural identity, while connecting them to underlying implications to gain social understanding for those inside and outside of the cultural group (Ellis, Adams \& Bochner, 2010). The researcher goes beyond simply analyzing previous significant events, as one must go further by explaining how their story has fundamental connectivity to the social word. The subjective researcher is able to take on a critically active role by immersing oneself throughout the research process (Carey, 2012). Also auto-ethnography involves removing the traditional label of a privileged objective outsider seeking to become part of a hidden subculture; instead one aims to understand cultural behaviors from an inside perspective (Carey, 2012). 
As a passionate member of the population of black queer women, this gives me a great desire to use a methodology that can allow for my positionality to be recognized as site of knowledge that possesses validity. A concrete strength to using auto-ethnography would be its potential to promote deeper connections and genuine empathy from readers of this work. The hope is that by using this methodology, readers can gain greater understanding about the lived experiences and rationales behind why particular struggles were experienced and the reasons for the behaviors that I engaged in. I believe that this methodology is the best way to effectively raise critical consciousness in our social world about supports, social services, and societal institutions which function to marginalize black queer female youth and hinders authentic identity expression. Inner conflict has negative consequences in relation to self-love. I aim to reveal how self-love becomes near impossible to achieve when one feels that they must compartmentalize aspects of their identities to fit into spaces and to make others feel comfortable with their presence. I choose to write from a subjective stance to resist remaining silent as silence promotes the oppression and violence enacted upon black females. Thus, this methodology will provide critical knowledge about some of the vast range of issues that black queer youth have from a qualitative perspective, by providing real lived context and analysis as to why these issues exist for youth such as me and what can be done to positively change them. I provide applicable insight into the nuances of these realities, as well as offering social understandings of the structural inequalities that continue to disadvantage black queer females. It also allows me to share applicable insight into the broader social understandings of the structural inequalities that continue to disadvantage black queer females. 
The data collection within this methodology was through the recollection of: memory, emotions, change within the self, as well as self-reported interactions with others (Carey, 2012). I gather a list of transformative events within my life that have had a significant influence on shaping my subjective perception of the world and identity as a black queer female within my communities. Out of this list I decided to focus on three transformative events that highlight encounters with a partner, an educational institution, and the institution of my family. An important factor in using auto-ethnography is the centering of critical reflexivity throughout the process. D'Cruz, Gillingham, and Melendez (2007) define critical reflexivity as "a critical approach to professional practice that questions how knowledge is generated and, further how, relations of power influence the processes of knowledge generation" (p. 77). As a researcher utilizing auto-ethnography, it is imperative that I continually look inward, particularly reflecting upon what tacit knowledges I possess and how power is fluid and complex in upholding what knowledges become taken for granted as truths that go unquestioned. The purpose of enacting critical self-reflexivity in my MRP, when discussing personal stories derived from memory, is to help me to flesh out the connections of identity erasure, realizing that they are related to the systemic and structural aspects of dominant society.

In conducting auto-ethnography, the Ryerson Research Ethics Board highlighted particular areas of concern that I had to acknowledge while engaging in this method. Firstly, relational ethics is essential to consider because as a researcher in this social world, what is written through the process can pose the risk of identifying those involved or implicated within the research being conducted (Ellis, Adams, \& Bochner, 2010). I obtained fully informed written consent from my family members that would be mentioned within my MRP, so that they would 
be aware about the nature of this research. When writing about crucial personal situations, I ensured that I took systematic protective measures to maintain the privacy and anonymity of those persons or places present during that experience. I made every attempt during the autoethnography process to strategically reduce the risk of identification of those in relation to my personal story, as I am aware that their exposure could pose reputational risks within their own personal lives. I will acknowledge that although this form of qualitative research is not generalizable in a traditional sense, it is still an important work that can positively produce learning about experiences of a person embodying a complex identity. Although I am writing from a shared cultural identity, this does not mean that all black queer females make sense of similar transformative experiences as I would. In addition, I must emphasize that there is a vast range of heterogeneity within this identity of black queer females, such that the meanings and experiences I have shared cannot be representative of all of the folks who are on this continuum.

Another noteworthy issue of conducting auto-ethnography would be that of measuring validity. The measurement of validity can be difficult within this type of qualitative research as the context and process is unique. Ellis, Adams and Bochner (2010) describe validity to be present within a work if it evokes a sense of credibility on behalf of the writer and that the emotionality within the story presented could resonate with readers. I strove to write my story as eloquently as possible, strategically selecting the ways in which I articulate my emotionality throughout in order to establish credibility. The strength of using this approach would be that auto-ethnography emphasizes the emotionality and power in lived experiences in the context of knowledge creation and research; reinforcing the immense value of lived stories in academia.

\section{$\underline{\text { Transformative Events \& Analysis }}$}


The events I will recall are those that I believe has since greatly impacted my well-being and pride. Although these events are where I experienced challenges, they are some places where I have learned lessons and gained substantial growth. The first experience speaks to instances of anti-black racism, misogynoir, and heterosexism. This scenario highlights the theme of unsafety to which I have been subject to.

On a dark summer night in the city, the streets were filled with life. I arranged to spend a weekend downtown with my partner at a local hotel as they decided to visit me in Toronto. After resting for quite some time, we decided to take a walk to see if we could find a place to grab some street food. It was nearing 4:00 a.m. in the morning, holding hands we began to cross a dark alley near a quiet college campus. To our surprise a group of four seemingly intoxicated young racialized men came out of the darkness and began striking up a conversation. I realized that there was no one else visibly around to witness this interaction taking place. They proceeded to interrogate the status of our relationship and presence in the space. One man made eye contact with me, rapidly asking multiple questions as to where we were staying in Toronto, where we lived, and what our plans were for the morning. I told them that we are not interested in spending any time with them, and that we were just trying to go get food privately. As the four men began to surround us, I felt Kyle's grasp tighten in my hand. Another one of the men took a step towards me asking me for my number. He suddenly quickly turned to Kyle, and apologized for asking this question. He tells Kyle, he can visibly see and respects that we are lesbians and that I am her girl. Afterwards, he asks Kyle to have her permission to get my phone number. Kyle explained to the man, that I am my own person and that if he is asking for my number then he should not be asking her as she does not give me permission to make decisions. Kyle explained 
that questions about me should be directed as such. He proceeded to excessively apologize, and asked me directly for my number. I replied by saying that I am not comfortable giving out my number in this situation, nor am I interested in any kind of relationship with the man. I saw the frustration mounting in the gazes of the men as they began raising their voices, asking us to go spend time with them as we appeared to not be busy. The fear inside me was rising, as I was unsure about how we could exit this potentially dangerous situation. Suddenly, an older man rushed up to the group of us and began asking for directions, saying he is lost in the city. This provided the needed distraction for us to quickly walk past the group of men and into the main streets filled with more lighting. In the darkness behind us, I could hear the men calling out asking us to return but we did not stop walking. To our relief, they decided to not follow. After getting food, I did not sleep much that night as I felt shaken by the events that transpired. Kyle did not leave my side the rest of the night.

This event displays the reality that racialized peoples can be racist too. Reflecting upon this situation with the players involved, has taught me the powerful ways in which my body is read when I am in a relationship with Kyle who is white. When historical context is put into focus the functionality of white supremacy in this strange encounter becomes clearer. I seek to critically question the privilege of masculinity in connection to queer gender expression and presentation. Although both Kyle and I felt uncomfortable, the interaction for me was particularly violent as a more femme presenting queer person. In this situation it becomes apparent that the men valued the opinions of my partner more based on the masculine ways they looked, clearly devaluing any words that were exchanged. Although the men realized that we were both queer, they still responded to Kyle in a more respectful way because they were being 
perceived as the "male" in the pairing through a heteronormative lens. I became very aware of how queer visibility becomes heightened when I am with people who explicitly self-present their gender identities outside of the assigned binary. The discomfort I faced in this situation is related to my heightened visibility as a queer person; most times in life I feel I lack visibility as I'm able to pass as a heterosexual woman. As we held hands, I was then perceived by the men as queer. When I reflect the way I am interpreted by most as a femme, this is undoubtedly connected to my gender expression and physical appearance. I find that because I present with longer hair, for example, the presumption of heterosexuality is almost expected. Despite the presence of my partner, I continued to be hypersexualized within a moment where the man proceeded to closely look at my body rather than my face while speaking. As a black woman, I was exoticized and viewed as an object rather than a person. The viewing of my body as an object of possession is clear when he tells Kyle, he can visibly see and respects that we are lesbians and that I am her girl. Afterwards, he asks Kyle to have her permission to get my phone number. At this point, I felt that our relationship was being devalued as a legitimate reality; it was simply dismissed. The dismissal is evident as the man proceeds to ask my partner for my number. This felt like a silencing of my voice, sexuality, and autonomy to speak. The misogynoir took the form of male privilege, where because I was visibly perceived as a female in contrast to everyone else in this encounter, my opinion and autonomy was not relevant to the conversation.

The hostility towards us that followed speaks to the entitlement that the men felt. Kindly explaining my disinterest resulted in this display. I can see the frustration mounting in the gazes of the men as they begin raising their voices asking us to go spend time with them as we appear to not be busy. To the men, I was seen as being noncompliant to their advances and invitation to 
go spend some time with them. Once their voices began to elevate, I felt afraid for my own safety as I knew that my life could be at risk. The situation was precarious, in that moment I was in a state of shock, unsure of whether I would have to fight for my life or if an opportunity to flee would arise.

In contrast, I noticed how the men viewed, spoke, and responded to Kyle was different from the treatment I received. There was not any pressure directed at Kyle that questioned the validity of their race, gender, or sexuality. This is evident as stated when Kyle explains that questions about me should be directed as such. He proceeds to excessively apologize, and asks me directly for my number. When Kyle reasserts this position, her authority is immediately heard and responded to. The greater respect and patience that was given to Kyle throughout this interaction connects to the unearned and assumed power that the men saw her in possession of. This recalls Puar's (2007) contention that white queers are viewed as worthy of state protection and privileges under the guise of white supremacy and freedoms while racialized others, such as myself, are not granted this treatment.

Therefore, Kyle's instructions to the men were honored, yet my own needs remained unheard and met with resistance. Although Kyle's superior treatment was undeniably tied to her queer masculinity and visibility. Their values and assumptions about masculinity being a fixed hegemonic reality dictated the ways that they responded to me with aggressiveness, entitlement, and superiority as their dominant position exists based upon their hegemonic ideas of femininity being everything masculinity is not and cannot be (Thomas, 2013). Gender can be vastly fluid, yet any opportunities for fluidity were ignored. Instead heteronormative gender roles where I was the woman and she was the man prevailed. Reflecting back to this experience has shown me how 
suffocating it can be as queer relationships are continuously pressured into mirroring presumed natural roles. These hegemonic roles come with great protection and privileges in our society. On some level tremendous violence was perpetuated against Kyle. The act of these strangers asking for Kyle's permission as my partner to obtain my number was interpreted by her as an offensive act of trespass and emasculation through the directed inquiry. I imagine in those moments Kyle felt similar emotions of being objectified and humiliated as I did. The men disregarded Kyle's existence as my queer partner, through aggressive questioning after I repeatedly expressed disinterest in their advances.

This second event took place while attending a Catholic high school in the suburbs. One winter morning, I was sitting in a room full of students. Prior to the beginning of a presentation, the instructor stated that student voices were coming into the classroom to share information with us. This was the first time that I ever heard the discussion of black history month being raised within the high school. The committee of white students that were representing the school asked the group to decide whether an elective course should be made available where students can learn about black history. As this question was asked I was sitting in a room filled with white students, who were the majority; there were a handful of racialized and black students. I recall that when the question was asked, the room fell silent and no hands were raised. The silence was broken by the representatives declaring that as a result of the vote or lack of participation, there would be no class offered which centred black histories in Canada. The student representatives proceeded to leave the room; the decision being made across an arrangement of blank faces. The committee announced that because of a lack of interested people, they will not go forth in 
ensuring the availability of a course focused on celebrating black lives. Afterwards the class begun as usual and there was no debriefing about the events that had taken place.

This situation was a critical turning point as it highlights the erasure of my existence, histories, and communities. In this educational environment, I felt that my black presence was read by my classmates as foreign. I recollect how the majority being Catholic white folks were immensely strategic in the ways they sought to maintain a racial hierarchy, where particular voices are heard and listened to over others. Reflecting on this situation, I realize that there was nothing neutral about what happened in the room. The tension I felt related to the moment where the committee of white students that were representing the school asked the group to decide as to whether an elective course should be made available where students can learn about black history. The problem with this language of an optional course offering is that it implies that black lives, histories, and experiences are things which are not of priority to learn about, nor is it worthwhile integrating into curricula. Black history should never have been presented as a choice to the whole group. I imagine the thought behind giving us choices was an attempt at fairness and equity, yet evident is the underlying white-supremacist logic was disguised as politeness. As a black queer youth in the space, I felt extremely uncomfortable and in shock that the essence of who I am as a person was treated as an option. This gave the majority students the power to decide the fate of the black and racialized students as we were severely outnumbered. Razack (1998) highlights:

Encounters between dominant and subordinate groups cannot be 'managed' simply as pedagogical moments requiring cultural, racial, or gender sensitivity. Without an understanding of how responses to subordinate groups are socially organized to sustain 
existing power arrangements, we cannot hope either to communicate across social hierarchies or to work to eliminate them. (p. 8)

Razack (1998) contends that encounters between white people who are the dominant people and racialized people cannot be analyzed with neutrality. Analysis requires naming the functionality within whiteness that seeks to protect the racial hierarchy, which cannot be eliminated without everyone working in solidarity across groups. What was missing from my experience in the classroom was the acknowledgment of whiteness in the room. A deeper discussion beyond sensitivity to difference was needed, where dominant groups acknowledged their misuse of power in the room through their strategic choice to introduce the course as optional, knowing that the majority who are white students are going to vote by remaining silent to maintain their comfort and privileges. By using the tactic of a purportedly 'democratic' 'majority wins' vote, the white people in the room effectively secured their protection through existing hierarchies of power. Simultaneously, as a black queer youth, my experience of the way the dominant group managed the exclusion of black lives was to pretend that they were invested in offering a course, when in reality there was no intention to have one. Having such a class would mean white students and faculty would have to face their whiteness, engage in racial justice, and do the work to center and include black students who are systemically marginalized in institutions of education. The wounds that I felt that day now have given me deeper understanding as to what really happened. That instance of feeling virtually alone in a room of white people will not be the last time. Educational institutions were not designed with the inclusion and safety of black lives in mind (Dei, 1996; James, 2001). 
At the time, I was not equipped with the knowledge and wisdom I have now. Navigating and surviving the institutions until this point have given me the tools to vocalize that what happened was not okay. I was in shock about what just happened, yet at the same time I did not break the white silence in that room or question their decision making process. Afterwards, for a long time I felt guilt and shame for not being the one to fight this battle and call out the complete lack of racial justice and representation. I had thought that the responsibility to fight for racial justice, decolonizing education, and inclusion was only the responsibility of racialized people. Historically the fight for black queer liberation has and continues to be led by racialized people, but white folks need to show up and stand in solidarity with communities, if we ever wish to end white supremacy. For inaction is a form of white supremacy; this inaction maintains social hierarchies which serve to harm and divide everyone.

This event was internalized as an experience of emotional trauma related to queer shame, where the self-doubt and despair I felt began to take over (Morrison, 2015). I recall that when the question was asked, the room fell silent and no hands were raised. The silence was broken by the representatives declaring that as a result of the vote or lack of participation there would be no class offered centering black histories in Canada. I critically question as to why I did not speak out amongst the few black students in the room. During this moment, I believed that my sole voice would not have enough of an impact, even though I would be participating in a class on black histories. At this time, I was had not yet publicly come out. I did not want to be singled out and labelled as the angry black queer woman, so instead I took no action. When the silence was broken by the decision being made to take the suggestion off the table, I felt my identity 
being erased. My inaction had limited the imaginations of everyone in that room including my own, furthering my displacement from the black queer communities to which I belong.

During the moments of silence, the main emotion being felt was fear. This fear held me back from advocating for what I really wanted and needed as an isolated black queer youth, who felt depression and anxiety. The fear of judgment from my peers was a strong inhibitor. A wiser self would use this fear as motivation to navigate through this situation as a healthy challenge. As a black youth in the room, I wrongly believed that I possessed no power to make any sort of change because the people in faculty positions held all of it. I know now that power is a fluid entity, and that regardless of identity there are sites of power and gifts that I have to strategically use to make positive changes to improve my own well-being as well as others. It was an important opportunity for disruption by asking critical questions and holding people accountable for their actions and intent behind institutional practices.

This final event in my life that I recollect is one that changed my outlook on life entirely. In the fall of 2012, a few days prior to my $19^{\text {th }}$ birthday a shock had befallen my family. As a teenager I had thought that my beautiful family was a constant unchanging stable force. When I was eighteen, my dad had been diagnosed with acute leukemia. Afterwards, he soon passed away at the hospital. An immense wave of sadness over took my being as I felt deep regret for not having conversations specifically about who I am with my dad. In the past, my parents suspected my queerness, and their questions would be met with denial. As the pressure mounted I finally mustered the courage to come out to my mom as a lesbian. This news was met with devastation and avoidance of me for weeks. Whenever I would see her in the house, she would be crying. When I would ask why, she would simply say that she did not want me to get mistreated by 
people in the world for who I am and this is why she wished I was not queer. Through this period of my mom grieving in silence, I did not go to my father to talk about this. I spent my time in isolation from my family, coping discreetly with heavy substance use as a way to numb the pain. I figure that my mom would have broken the news to him soon after my disclosure. Regardless, my dad never gave me an indication that he was aware of this information or that he had an issue about it. I assumed that due to my parents' conservative cultural upbringings, they would likely reject who I am. After my father had died, I remember finally asking my mom what he said when he found out. She told me that he reassured her that the girls were going to grow up just fine as they are. The year prior, my twin sister Carmen had revealed to my mom that she is a lesbian, which was not received well. My father told my mother that he accepted and loved me for who I am regardless of my sexual orientation. This revelation by my mom came to me as a shock. I deeply longed to have a conversation with my dad about what his thought process was as he, my parent, came to the decision to welcome and love who I am.

Examining the transformative stage of coming out in a Western Canadian context, I now see the pressures experienced by my family of coming out as part of a larger colonial narrative. The coming out narrative in the West serves to function as a part of homonationalism through normalized institutional practices (Puar, 2007) such as National Coming out Day. As a youth, I experienced extreme distress as the pressure to come out was mounting beginning with the suspicions in the institution of my family. As a youth, I believed that coming out was a significant stage in life, as this was the normalized public messaging. Coming out is an inherently political action where a person declares for public consumption that their experience of gender/and or sexual identity is non-normative. According to Sedgwick (2008), "[T]he closet 
is the defining structure for gay oppression in this century" (p. 71). This analogy seemingly comes with the promise that if one surrenders to the pressures of coming out, to no longer repress their sexuality, then the suffering attached to secrecy will end. The issue with the coming out narrative as constantly being portrayed positively is that it does not account for the reasons why it might be a choice to not come out, as it may be unsafe and uncomfortable in their current environments to do so. What I did not realize at the time was that coming out as a racialized queer person had very different implications and struggles as opposed to if I were a white person. The positive visibility and institutional privileges associated with homonormativity are granted to white queer folks (Kacere, 2015). With this 'coming out' narrative in mind, I thought that I had to declare a final decision to my family as to how I would self-identify. In the past my parents suspected my queerness, and their questions would be met with denial. As the pressure mounted I finally mustered the courage to reluctantly come out as a lesbian to my mom. Through denial by omission, I avoided the reality that I was not living up to my family's Black Latino heteronormative expectations of performing gender and sexuality (Acosta, 2010). The external pressures of the colonial coming out narrative had my subconscious in distress about how I would articulate my sexual identity. The reality of my sexual identity was foreign to my parents. I was also not entirely sure that the category of lesbian encapsulated all that I felt gender and sexuality wise. I knew that I was a same-gender loving person; I figured that the only option available to validate this entirely was to say that I was a lesbian.

I can now see my thinking process as a complex web of negotiations as to what was possible for my own queerness; rather than imagining infinite possibilities, I restricted them. Even after coming out, I thought that this would relieve me of being surveilled and questioned, 
yet this continued in a different way. The revelation of my identity was met with consistent doubt, or reassurance that this was likely a phase in youth that I would eventually grow out of. This news was met with devastation and avoidance of me for weeks. Whenever I would see her in the house, she would be crying. When I would ask why, she would simply say that she did not want me to get mistreated by people in the world for who I am, and this is why she wished I was not queer.

I saw this as a grieving for the person that my mother expected and hoped I would be. I initially received this grieving in the form of visible sadness as offensive. I felt that the mourning she expressed was coming from a place of homophobic judgment rather than love. In reflection, I know that my mom was upset because she knew first hand that this world is dangerous, that brutality and violence is a reality for queer people. This experience of feeling that I had to come out was a precarious one. The silence that I experienced from my parents once I made the disclosure of my queerness was interpreted as a practice of erasure. The pain of feeling that I had disappointed them as their child for being queer was intense. The intensity of my emotions of anxiety and depression became overwhelming, as my sense of belonging within my black Latino family was shaken. This uncertain state with little community supports available in the suburbs exacerbated my experiences of struggling to know that who I am is an acceptable experience, and also one to be proud of.

This lesbian identity caused me distress as I felt that once I claimed to be one within the mainstream queer community, I would have to repress any desires or changes in my gender/sexual identity. Feeling any other desires or attractions that did not align with what the mainstream state definition was of lesbian meant the believability of my same-gender desires 
would go under suspicion. I now can see how the strict categorization, in addition to separation within the LGBTQ acronym and the existence of state sanctioned entities such as National Coming Out Day shaped and limited my understanding of all that I am. The coming out narrative serves to uphold white supremacy that maintains the racial hierarchies of white domination through homonormativity, where the experiences that racialized and Indigenous people have with gender as well as sexuality continue to be out of focus. By being complicit in thinking that I had to announce to the public and the institution of my family that I was a lesbian, I unknowingly participated in a wider colonial project. I would experience continual exclusion from the mainstream queer community as it was never intended to be a welcoming space for black queer youth to be free and celebrate existing diversity (Acosta, 2010; James, 2001; Rwigema, Udegbe, \& Lewis-Peart, 2015).

After this loss of my dad, in grief I realized that he had always known from a young age that I was different. I was under the assumption that he had no awareness of my feelings, yet his consistent acts of kindness were his ways of communicating his unconditional love and understanding. For a long time, I was plagued with guilt for not having the courage to connect with my dad to personally express the authenticity of myself. I had let fear inhibit opportunities involving risk for a deeper connection with my family which ended up hurting me. The relationship I have with my dad has taught me that black love can know no limits, and that it is the cure to embracing who I truly am.

\section{Overall Findings}


Through this research process, I have found two key findings to share. Firstly, autoethnography is an effective methodology for breaking the silence as black queer female's realities, by providing an opportunity to center, recognize, and name the experiences I have had as part of greater systemic forces within institutions intentionally designed to disadvantage and harm black people. Engaging in this writing has given me insight as to how the erasure of my dynamic identity is tied to the colonial project where the control and surveillance of black people is prioritized. I have learned that the act of giving voice to and sharing the experiences I embody is an act of resistance against the systems that are invested in furthering the displacement and separation of who I am from my communities. The only way to fight back is with community building and sharing radical black love. In this climate of white supremacy and domination our black bodies are often harmed, blamed, and unappreciated; by choosing to celebrate our bodies we are engaging in resistance towards liberating our minds and hearts. This journey has allowed me to clearly see that I was, at times, unwell and in distress as I was unable as a youth to understand why I felt displaced at times even in communities that were framed as all welcoming spaces. The shame and guilt that I carried with me as a youth can be connected to the internalization of oppression. After many painful experiences, I began to just believe the violent comments people would say about all the components of my identity and appearance. This gave rise to the devaluing and hatred of the self, so I would cope in unhealthy ways in attempts to avoid or mask feelings of pain. I know that black self-love is the answer to embracing who I am and feeling unapologetically proud. I continue to be on this journey of discovering ways to love who I am as a black queer woman in a world that has taught me otherwise. In Shraya's (2013) anthology of queer voices, Eddie Ndopu beautifully states the following: 
Queer fits. It fits because it encapsulates the dynamism of my sexuality without imposing restrictions on my gender expression. Queer makes room for my femme ness and dis ability embodiment in a way that gay and same gender loving doesn't. For me, queer means radiant darkness, radical love, and a million and one ways to resist and decolonize. (p. 33)

As I grow into self-discovery, I now embrace queerness as I believe that it can fully encompass the possibilities for change and fluidity without imposing any limitations (Shraya, 2013). Embracing queerness has given light to seeing how there are many ways to radically decolonize the self, and offer pathways to knowing what pride can feel like. In-depth reflection and rigorous analyses that is auto-ethnography has been a challenge as it makes one confront painful experiences. In the past, I would seek to avoid any sorts of additional pain that would come from self-reflection of painful events, even if possible lessons were present. Choosing to do auto-ethnography has provided an avenue for healing, as I purposely chose this methodology to break the inner silence that has been restricting possibilities on working through my emotions. Auto-ethnography is an effective methodology to raise the critical consciousness of others who shared similar experiences such as mine, as well as others who do not. It provides a perspective into the nuances, difficulties, and triumphs of a black queer woman, thus inviting people to make connections of their experiences to broader societal forces. It allows for those who are a part of my communities to know that they are not facing their struggles in isolation, and that possibilities to connect with others for healing within community exists.

\section{$\underline{\text { Implications }}$}


The first implication that can be drawn from engaging in auto-ethnography as a methodology is that it is an excellent approach to raise the critical consciousness of peoples in and outside of my communities. This qualitative approach obtains credibility through the believability and the emotionality that comes with the telling of lived stories. The stories that I have shared allow readers to deeply connect with the issues of violence and injustice that exist in black lives. Greater support and space must be given in academia for creative and artistic approaches including auto-ethnography, to give space for black folks to tell their valuable experiences that can help shape a better new world for everyone. I encourage educators and researchers to support black students in solidarity to pursue creative methodologies that best allow them to express who they are in ways that they feel recognized and respected for their contributions.

The ways in which black queer women's voices and bodies are silenced, violated, and surveilled need to be addressed by institutions at structural and micro levels. The oppressions that black queer women face through anti-black racism and misogynoir are pervasive realities that must be dismantled by exposing the source of the problem. Oftentimes, in society problems of inequity are portrayed as individuals simply not trying hard enough. This diverts attention away from corruption within state institutions focusing on self-blame as if black peoples are at fault for the multiple forms of trauma, erasure, and violence they experience. Service providers at all levels of organizations in the city of Toronto must act in solidarity with black communities to fight against the state as the injustice that has and continues to happen is part of a harmful capitalist system corrupt in creation and design. 
This research provides further detail as to how seemingly everyday events that occur within the institutions of families, education systems, and in the public are in actuality transformative events that have been sites of trauma, growth, and healing. My blackness has and will shape the interactions that I have with those in my communities and those who are strangers. Service providers working with black queer people need to understand the fluidity and complexity of race, sexuality, and gender. To effectively support and work with black communities greater efforts need to be made by the state and organizations to decolonize and create black centered spaces where people can receive services that respect every part of who they are. Regardless of where I go, I should be able to receive services from black and queer organizations with confidence that my needs, comfort, and experiences are going to be heard and responded to.

To those working in solidarity with my communities, I strongly advise if they have not already done so, to connect with and work in support of Black Lives Matter Toronto (BLMTO). The work of BLMTO is continually inspirational and rooted in strategic actions that emphasize the importance of all black lives including queer and trans lives. The mission of BLMTO reads, "To forge critical, connections and to work in solidarity with black communities, black-centric networks, solidarity movements, and allies in order to dismantle all forms of state sanctioned oppression, violence, and brutality committed against African, Caribbean, and Black cis, queer, trans, and disabled populations in Toronto" (Black Lives Matter, 2016). For the tireless work of all the folks actively involved who organize and devote everyday of their lives to this work of fighting for all black lives, I am endlessly grateful and blessed. Discovering and participating in 
BLMTO organized events has raised visibility and an authentic experience of belonging where I know that I have people who accept and love me for all that I am.

Engaging with BLMTO has given me what I lacked most in my youth - direction and positive mentors who advocate for liberation, justice, and healing. Toronto should focus funding towards resources that create more spaces and programming on exploring the desires, needs, and challenges of black queer youth. These spaces must strive to create a safer environment where black queer youth community engagement facilitates their well-being. An example of this would be programs such as Black Queer Youth at Supporting Our Youth (SOY) which is run out of the Sherbourne Health Centre. Drop-in welcoming spaces should be expanded to exist across the Greater Toronto Area. Growing up for most of my youth in an inaccessible white suburb where exclusionary practices and policies are the norm, I began to entertain the idea that I somehow deserved this constant mistreatment. For many black queer youth gaining access and connections to community can improve their quality of life substantially, and even save lives and as it did for me. There is a dire need for greater community health services for black youth. However, I do caution the need for workers to remember that there is not only one way of supporting black folks to obtain wellness. We live in a society that is focused on over medicating folks, particularly black bodies. As a result, the mental health challenges black people experience is frequently framed by mainstream media accounts where black people are stereotyped as dangerous and unpredictable. Mainstream media fails to discuss how the symptoms being felt by black people are caused by a system that sets them up to experience a multitude of barriers that cause mental health challenges. Emphasizing the need for black people to be on medications as the only form of health care is problematic, as it is another way to control, subdue, and continue 
societal surveillance. Although medication can be helpful for some, continued efforts need to be focused on community based initiatives that openly discuss other pathways to experiencing wellbeing.

\section{Conclusion}

In summary, this research serves as a way to begin crucial conversation from a personal insider perspective, shedding light on experiences of pride and well-being. The erasure of my identity within society is explored focusing on expressing the emotionality and complex ways in which it affects my world view and relationships. The implications for various service providers, social workers, and community members is that intersectional efforts must be made to decolonize, include, and meaningfully welcome black queer women. This must be done in a way that affirms the integral part that they constitute in queer-black communities throughout history. People from black and queer communities must engage in constant self-reflection to take notice of appropriate actions towards addressing the realities of homonormativity, misogynoir, and heterosexism that black queer women face every day of their lives. Supports for services and programs for black queer youth need to be advocated for.

I believe that wellness is a complex journey rather than a fixed destination. There are certainly a variety of ways to facilitate wellness, beginning with ongoing resistance and sharing of experiences with other black queer youth. By sharing experiences, black queer youth can attain knowledge that there are possibilities to experience pride and liberation in this dynamic world. The suffering I experienced was related to isolation from black queer folks within my communities as this was a group I was sheltered from connecting with for a long time. I am a 
strong advocate for more diverse and accessible targeted resources and programming that address the challenges that black queer women face. In my experience, the lack of mentors and supportive services contributed to the struggles of self-love and acceptance which I learned. The hope is that this research provides an alternative insight away from medical models, that speaks to some difficulties and triumphs I experienced. I acknowledge that my lived experiences of erasure from the queer communities and black communities in my life are unique. These experiences have taught myself that self-liberation begins with self-acceptance of all that I am; regardless of how others are going to respond I will feel well when my actions and how I am feeling align. Through rigorous reflection I have learned more about how my experiences of erasure are not unintentional, rather they are strategic and have required tireless resistance. 


\section{References}

Acosta, K. (2010). How could you do this to me? How lesbian, bisexual, and queer Latinas negotiate sexual identity with their families. Black Women, Gender \& Families, 4(1), 6385. doi:10.1353/bwg.0.0014

Adams, T. E., \& Manning, J. (2015). Autoethnography and family research. Journal of Family $\backslash$ Theory \& Review, 7(4), 350-366. doi:10.1111/jftr.12116

Alears, J. (2010). Two-spirited people and social work practice: Exploring the history of Aboriginal gender and sexual diversity. Critical Social Work, 11(1), 63-79.

Bailey, M. (2010). They aren't talking about me. The crunk feminist collective. Retrieved from http://www.crunkfeministcollective.com/2010/03/14/they-arent-talking-about-me/

Baskin, C. (2016). Strong helpers' teachings: The value of Indigenous knowledges in the helping professions. Toronto, ON: Canadian Scholars' Press.

Battle, J., \& DeFreece, A. (2014). The impact of community involvement, religion, and spirituality on happiness and health among a national sample of black lesbians. Women, Gender and families of color, 2(1), 1-22.

Benjamin, L. A. (2005). The Black/Jamaican criminal: The making of ideology. Unpublished doctoral thesis. National Library of Canada= Bibliothèque nationale du Canada.

Black Lives Matter. (2016). All black lives matter. Black lives matter Toronto. Retrieved from https://blacklivesmatter.ca/about/

Bowleg, L., Craig, M. L., \& Burkholder, G. (2004). Rising and surviving: A conceptual model of 
active coping among black lesbians. Cultural Diversity and Ethnic Minority Psychology, 10(3), 229-240.

Bowleg, L., Huang, J., Brooks, K., Black, A., \& Burkholder, G. (2003). Triple jeopardy and beyond: Multiple minority stress and resilience among black lesbians. Journal of Lesbian Studies, 7(4), 87-108.), 229-240.

Browne, K. \& Nash, C. (2010). Queer methods and methodologies: Intersecting queer theories and social science research. Surrey, United Kingdom: Ashgate Publishing.

Butler, J. (2009). Performativity, precarity and sexual politics. AIBR. Revista de Antropología Iberoamericana, 4(3), 1-12.

Carey, M. (2012). Qualitative research skills for social work: Theory and practice. Surrey, England: Ashgate Publishing limited.

Carniol, B. (2000). Case critical: Social services \& social justice in Canada. Toronto: Between the Lines.

Carter, S., \& Little, M. (2007). Justifying knowledge, justifying method, taking action: Epistemologies, methodologies, and methods in qualitative research. Qualitative Health Research, 17(10), 1316-1328.

Childers-McKee, C. D., \& Hytten, K. (2015). Critical race feminism and the complex challenges of educational reform. The Urban Review, 47(3), 393-412. doi:10.1007/s11256-015-0323-z.

Cramer, R. J., Johnson, J. C., Crosby, J. W., Henderson, C. E., La Guardia, A. C., \& Stroud, C. H. (2016). Personality, coping and mental health among lesbian, gay, and bisexual community members. Personality and Individual Differences, 96, 272-278.

Crenshaw, K. (1989) Demarginalizing the intersection of race and sex: A black 
feminist critique of antidiscrimination doctrine, feminist theory and antiracist politics. University of Chicago Legal Forum 138-67.

Creswell, J. W. (2007). Qualitative inquiry and research design: Choosing among five approaches. Thousand Oaks, California: sage publications inc.

D'Cruz, H., Gillingham, P., \& Melendez, S. (2007). Reflexivity, its meanings and relevance for social work: A critical review of the literature. The British Journal of Social Work, 37(1), 73-90. doi:10.1093/bjsw/bcl001

Dei, G. (1996). Anti-racism education; Theory and Practice. Halifax: Fernwood Publishing.

Ellis, C., Adams, T. E., \& Bochner, A. P. (2010). Autoethnography: An overview. Astrolabio: Nueva Época, (14), 249-273.

Eng, D.L., Halberstam, J., \& Muñoz, J.E. (2005). What's queer about queer studies now? Introduction. Social Text, 23(3-4, 84-85), 1-17. doi: 10.1215/01642472-23-3-4_84-85-1

Eng, D. L. (2010). The feeling of kinship: Queer liberalism and the racialization of intimacy. Durham, NC: Duke University Press.

Few, A. L. (2007). Integrating black consciousness and critical race feminism into family studies research. Journal of Family Issues, 28(4), 452-473. doi:10.1177/0192513X06297330

Fingerhut, A. W., Peplau, L. A., \& Ghavami, N. (2005). A dual-identity framework for understanding lesbian experience. Psychology of Women Quarterly, 29(2), 129-139.

Greensmith, C., \& Giwa, S. (2013). Challenging settler colonialism in contemporary queer politics: Settler homonationalism, pride Toronto, and two-spirit subjectivities. American Indian Culture and Research Journal, 37(2), 129-148. 
hooks, b. (1989). Talking back: Thinking feminist, thinking black. New York: South End Press.

Hsieh, N., \& Ruther, M. (2016). Sexual minority health and health risk factors: Intersection effects of gender, race, and sexual identity. American Journal of Preventive Medicine, $50(6), 746$.

Jackson, S. (2006). Interchanges: Gender, sexuality and heterosexuality: The complexity (and limits) of heteronormativity. Feminist Theory, 7(1), 105-121.

doi:10.1177/1464700106061462

James, C. E. (2001). Multiculturalism, diversity, and education in the Canadian context: The search for an inclusive pedagogy. Global constructions of multicultural education: Theories and realities, 175-204.

Kacere, L. (2015). Homonormativity 101: What it is and how it's hurting our movement. Everyday Feminism. Retrieved from http://everydayfeminism.com/2015/01/homonormativity-101/

King, J. (2006). Outing the center: Homophobia in Jamaica. Independent Study Project (ISP) Collection. 380 .

Lehavot, K., \& Simoni, J. M. (2011). The impact of minority stress on mental health and substance use among sexual minority women. Journal of Consulting and Clinical Psychology, 79(2), 159-170.

Lopez, C. R., Antoni, M. H., Fekete, E. M., \& Penedo, F. J. (2012). Ethnic identity and perceived stress in HIV+ minority women: The role of coping self-efficacy and social support. International Journal of Behavioral Medicine, 19(1), 23-28.

McCready, L. T. (2004). Some challenges facing queer youth programs in urban high 
Schools: Racial segregation and de-normalizing whiteness. Journal of Gay \& Lesbian Issues in Education, 1(3), 37-51. doi:10.1300/J367v01n03_05

Mollen, D., \& Stabb, S. D. (2010). Women's sexuality and meaning making. Journal of Constructivist Psychology, 23(4), 295-320.

Morrison, M. (2015). 'Some things are better left unsaid': The 'dignity of queer shame'. Mosaic: A Journal for the Interdisciplinary Study of Literature, 48(1), 17.

Mullings, D.V. (2016). Social work education: Exploring pitfalls and promises in teaching about black queer older adults. In S. Hillock \& N. Mulé (Eds.), Queering social work education (pp. 205-226). Vancouver, BC: UBC Press.

Muñoz, J. E. (2009). Cruising utopia: The then and there of queer futurity. New York: New York University.

Oswin, N. (2008). Critical geographies and the uses of sexuality: deconstructing queer space. Progress in Human Geography, 32(1), 89-103.

Pon, G., Gosine, K., \& Phillips, D. (2011). Immediate response: Addressing anti-native and antiblack racism in child welfare. International Journal of Child, Youth and Family Studies, $3 \& 4,385-409$.

Poon, M. K. L. (2006). The discourse of oppression in contemporary gay Asian diasporal literature: Liberation or limitation? Sexuality \& Culture, 10 (3): 29-58.

Puar, J. (2007). Terrorist assemblages: Homonationalism in queer times. Durham, NC: Duke University Press.

Razack, S. (1998). Looking white people in the eye: Gender, race, and culture in courtrooms and classrooms. Toronto, ON: University of Toronto Press. 
Razack, S., Smith, M., \& Thobani, S. (2010). States of race: Critical race Feminism for the 21st century. Toronto: Between the Lines.

Rwigema, M., Udegbe, O., \& Peart, D. (2015). "We are expected to work as if we are not who we are": Reflections on working with queer Black youth. In B. O'Neil, T. Swan, \& N. Mule (Eds.), LGBTQ people and social work (pp. 37-52). Toronto, ON: Canadian Scholars' Press.

Rosario, M., Schrimshaw, E. W., \& Hunter, J. (2004). Ethnic/racial differences in the comingout process of lesbian, gay, and bisexual youths: A comparison of sexual identity development over time. Cultural Diversity and Ethnic Minority Psychology, 10(3), 215228.

Rothblum, E. D., \& Factor, R. (2001). Lesbians and their sisters as a control group: Demographic and mental health factors. Psychological Science, 12(1), 63-69.

Sedgwick, E. K. (2008). Epistemology of the closet (Update with a new preface. ed.) California: University of California Press.

Shraya, V. (2013). What I love about being queer. George Brown College Diversity, Equity \& Human Rights Services. Toronto: Warren's Waterless Printing.

Sutter, M., \& Perrin, P. B. (2016). Discrimination, mental health, and suicidal ideation among LGBTQ people of color. Journal of Counseling Psychology, 63(1), 98-105.

Szymanski, D. M., \& Chung, Y. B. (2001). The lesbian internalized homophobia scale: A Rational/Theoretical approach. Journal of Homosexuality, 41(2), 37-52.

Szymanski, D. M. (2006). Does internalized heterosexism moderate the link between heterosexist events and lesbians' psychological distress? Sex Roles, 54(3), 227-234. 
Thomas, K. D. (2013). Deconstructing hegemonic masculinity: Understanding representations of black and white manhood in print advertising. Advertising \& Society Review, 14(2), Advertising Educational Foundation. Retrieved July 19, 2017, from Project MUSE database.

Ware, S.M. (2017). All power to all people? Black LGBTTI2QQ Activism, Remembrance, and Archiving in Toronto. Transgender Studies Quarterly, 2(4), 170-180.

Williams, P. J. (2016). Seeing a color-blind future: The paradox of race. (5th ed.), (3-61). New York: the Noonday Press: Farrar Straus and Giroux.

Willis, J. W., \& Jost, M. (2007). Foundations of qualitative research: Interpretive and critical approaches. Thousand Oaks California: Sage Publications.

Wing, A. K., \& Willis, C. A. (1999). From theory to praxis: Black women, gangs, and critical race feminism. La Raza Law Journal, 11(1), 1-15. 